\title{
AKTIVISME TAGAR \#PERCUMALAPORPOLISI SEBAGAI ZEITGEIST DEMOKRASI SIBER DI INDONESIA
}

\author{
Nur Indah Wuriani \\ Universitas Diponegoro, Semarang, Indonesia \\ indahsalimin@students.undip.co.id
}

Submitted: 11-11-2021, Revision: 30-11-2021, Accepted: 08-12-2021

\begin{abstract}
The uses of hashtag (\#) in social media especially Twitter are no longer segmented for building popular conversation related to entertainment topics or trendings. Twitter users actively use hashtags to involve themselves in some political issues, in order to amplify some collective movements or merely to share their opinions and attitudes on specific issues. The concept is known as hashtag activism. Hashtag activism as a part of cyber democracy could only happen in two conditions, when the internet has widely penetrated the society and the uses of social media are becoming more common in the society. This research proposes that hashtag activism is scientifically satisfied four formal properties of cyber democracy's zeitgeist which are duration, scope, course also media and carrier, especially in Indonesia. Through netnography method and the usage Talkwalker, an automatic hashtag analyzer, the research focuses on analyzing the elements of formal properties of Zeitgeist in hashtag \#PercumaLaporPolisi on Twitter.
\end{abstract}

Keywords: hashtag activism, cyber democracy, zeitgeist, Twitter

\begin{abstract}
Abstrak
Penggunaan tagar atau tanda pagar (\#) di media sosial khususnya Twitter tidak hanya berperan dalam membangun pembicaraan populer terkait hiburan maupun tren terkini. Pengguna Twitter secara aktif menggunakan tagar untuk melibatkan diri terhadap isu politik yang sedang berlangsung, sarana menunjukkan sikap terhadap isu tertentu dan menghimpun gerakan kolektif. Konsep ini biasa disebut dengan aktivisme tagar. Aktivisme tagar sebagai bagian dari demokrasi siber hanya bisa terjadi pada era digital ketika penetrasi internet telah merata dan penggunaan media sosial telah dikuasai dengan baik oleh masyarakat. Penelitian ini bertujuan untuk membuktikan bahwa aktivisme tagar seperti \#PercumaLaporPolisi telah memenuhi empat elemen properti formal sebagai zeitgeist demokrasi siber khususnya di Indonesia. Melalui metode netnografi peneliti menelaah elemen properti formal zeitgeist pada penggunaan tagar di Twitter. Berdasarkan hasil analisis linimasa Twitter dan data yang diperoleh dari software Talkwalker terkait tagar \#PercumaLaporPolisi, ditemukan bahwa aktivisme tagar telah memenuhi empat properti formal zeitgeist sebagai bagian dari demokrasi siber yakni duration, scope, course serta media and carrier.
\end{abstract}

Kata kunci: aktivisme tagar, demokrasi siber, zeitgeist, Twitter

\section{PENDAHULUAN}

Twitter merupakan media sosial besutan Jack Dorsey yang pertama kali dirilis pada 2006. Kemunculan media sosial ini menjadi alternatif bagi Facebook yang dianggap terlalu kompleks. Sebagai media sosial alternatif, Twitter berhasil menarik perhatian dengan kesederhanaan media sebagai kekuatan utama. Pada awal kemunculannya, Twitter hanya dapat digunakan untuk membagikan konten berupa teks yang jumlah karakternya dibatasi hanya 140 karakter. Hal ini tidak terlepas dari latar belakang Twitter yang sempat disebut sebagai layanan teks berdasarkan SMS (Short Message Service). Seperti diketahui, SMS juga membatasi karakter maksimal sejumlah 160 karakter. 
Meski kemudian fitur dan batasan karakter di Twitter terus berkembang hingga 280 karakter, kemudahan berbagi pikiran melalui medium teks membuat Twitter sukses mengambil hati pengguna media sosial di dunia, termasuk di Indonesia.

Indonesia tercatat menjadi negara dengan pengguna Twitter yang besar. Pada 2012 Indonesia tercatat sebagai negara kelima di dunia dengan pengguna Twitter terbanyak. Pada tahun ini, jumlah pengguna Twitter di Indonesia mencapai 19,5 juta pengguna (Kementerian Komunikasi Dan Informatika, n.d.). Jumlah ini menurun pada angka 15.7 juta pada 2021 (Global Twitter User Age Distribution 2021 | Statista, n.d.) namun dengan berkembangnya berbagai media sosial lain seperti TikTok dan Instagram, performa Twitter dalam mempertahankan penggunanya, masih tergolong cukup baik.

Sebagai media sosial microblogging dengan layanan utama berupa tweet atau cuitan dengan batasan sebanyak 280 karakter (Saifulloh \& Ernanda, 2018), Twitter menjadi sarana penggunanya dalam mengunggah konten-konten sederhana dalam format beragam mulai dari teks, foto, video maupun gambar bergerak (GIF). Seorang pengguna juga bisa melakukan interaksi pada pengguna lain melalui "mention" yakni dengan menuliskan simbol “@” sebelum nama pengguna yang ingin disebutnya. Pengguna juga dapat saling berinteraksi dengan membalas cuitan satu sama lain, atau mengomentari sebuah cuitan melalui fitur "Quote Retweet".

Tidak hanya berupa teks, gambar atau video, pengguna Twitter juga dapat menyertakan tanda pagar atau tagar (hashtag) dalam setiap unggahan mereka di Twitter. Tagar biasanya berupa kata atau frasa yang ditulis menggunakan simbol "\#”" (Twitter Glossarium, 2021).

Bukan sebatas pemanis, tagar menjadi elemen yang memiliki signifikansi di Twitter. Dengan mengklik sebuah tagar, pengguna Twitter dapat melihat tweet atau cuitan yang mengandung topik atau kata kunci yang sama (Carley et al., 2018). Tagar menempati peran beragam di Twitter seperti sebagai label, rangkuman dan indikator topik. Melalui penggunaan tagar, pengguna dapat bergabung dalam sebuah percakapan yang juga sedang banyak dibicarakan pengguna lainnya. Tidak hanya itu, melalui tagar pengguna juga dapat saling menemukan pengguna lain yang sebelumnya mungkin tidak terhubung dengan mereka (Carley et al., 2018)

Pentingnya tagar dalam Twitter tidak hanya berpusar pada pembicaraan terkait tren terbaru dalam ranah hiburan, namun juga topik-topik lain yang sifatnya progresif. Berbagai riset menyebut bahwa pengguna Twitter terdiri dari berbagai macam golongan yang menggunakan platform ini untuk berbagai kepentingan berbeda. Riset menunjukkan ekosistem Twitter terdiri berbagai hal seperti brand yang berusaha menjangkau audiens mereka, bot yang terotomatisasi, pengguna yang mengikuti selebritas, para perisak yang gemar melakukan cyber bullying, hingga para pengguna yang gemar terlibat dalam diskusi terkait topik politik (Carley et al., 2018).

Dengan jumlah pengguna yang besar, Twitter menjadi platform yang ideal bagi warganet untuk melakukan sebuah gerakan sosial maupun politik, salah satunya berupa aktivisme tagar. Pemanfaatan tagar sebagai bagian dari aktivisme digital telah diteliti dalam penelitian terdahulu seperti oleh Bonila dan Rosa (Bonilla \& Rosa, 2015), Clark (Clark, 2016) dan Yang (Yang, 2016). Aktivisme tagar atau hashtag activism merupakan sebuah upaya menghimpun protes yang tersebar di media sosial melalui tagar berupa kata, frasa atau kalimat (Yang, 2016). Keberhasilan penggunaan tagar sebagai bagian dari aktivisme digital salah satunya dapat kita lihat dari dua kasus seperti pada \#BlackLivesMatter dan \#Ferguson. Melalui dua tagar ini, pengguna Twitter mampu mendulang perhatian besar dari masyarakat dunia mengenai tindakan rasialis dan melanggar hak asasi manusia oleh 
oknum kepolisian Amerika Serikat kepada warga berkulit hitam di negara tersebut (Bonilla \& Rosa, 2015), (Yang, 2016).

Penelitian yang secara khusus mendiskusikan aktivisme media sosial di Indonesia, termasuk Twitter dilakukan oleh Lim pada 2013. Melalui penelitian ini, Lim (Lim, 2013) menemukan bahwa dua kasus aktivisme tagar yang pertama kali muncul dan meraih keberhasilan di Indonesia yakni tagar \#KoinUntukPrita dan \#CicakVSBuaya. Melalui penelitian ini, Lim juga menyampaikan hasil analisis bahwa sebuah gerakan aktivisme melalui media sosial di Indonesia, memiliki potensi besar untuk berhasil jika dilaksanakan dalam beberapa kondisi yakni 1) isu yang dibawa merupakan isu yang sederhana (tidak kompleks), 2) sejalan dengan narasi media mainstream, 3) narasi, simbol dan ikon yang digunakan menyesuaikan budaya kontemporer populer, dan 4) tidak bertentangan dengan ideologi atau pandangan dominan.

Jika tagar \#KoinUntukPrita dan \#CicakVSBuaya berhasil mencuri perhatian besar pada tahun 2009, salah satu tagar yang sempat menjadi trending topic di Twitter pada Oktober 2021 dan menjadi perbincangan yang luas adalah tagar \#PercumaLaporPolisi. Tagar ini muncul sebagai reaksi masyarakat terhadap kasus pemerkosaan tiga orang anak oleh ayah kandung mereka sendiri yang merupakan seorang ASN (Aparatur Sipil Negara) di Kabupaten Luwu Timur, Sulawesi Selatan. Kasus ini pertama kali dipublikasikan melalui berita berjudul "Tiga Anak Saya Diperkosa, Saya Lapor ke Polisi, Polisi Menghentikan Penyelidikan" oleh media online projectmultatuli.org pada 6 Oktober 2021 (Tiga Anak Saya Diperkosa, Saya Lapor Ke Polisi. Polisi Menghentikan Penyelidikan. - Project Multatuli, n.d.). Paparan kronologis kasus tersebut membuat publik marah karena upaya Sang Ibu untuk melaporkan suaminya ke kepolisian setempat justru ditolak dan penyelidikan dihentikan secara sepihak oleh kepolisian. Berbagai pihak menuding adanya unsur keberpihakan kepolisian kepada terlapor karena menghentikan proses penyelidikan begitu saja.

Tidak berhenti sampai di situ, kemarahan publik kian menjadi-jadi ketika Polres Luwu Timur melabeli berita ini sebagai hoaks melalui akun Instagram resmi mereka. Pada Gambar 1 kita dapat melihat unggahan di media sosial Instagram resmi Polres Luwu yang menyertakan identitas Ibu korban serta hasil visum sehingga membuat publik marah karena dianggap tidak menjaga kerahasiaan identitas korban dan Ibunya. Publik menilai, pihak Kepolisian Luwu Timur tidak sepantasnya memublikasikan hasil visum, tidak melindungi identitas korban, serta dengan tidak bertanggung jawab melabeli sebuah berita sebagai hoaks atau berita bohong.

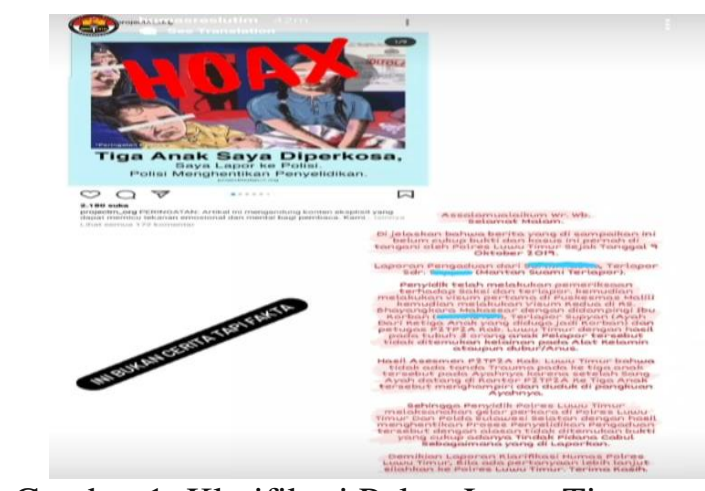

Gambar 1: Klarifikasi Polres Luwu Timur yang melabeli berita sebagai hoaks

(Sumber: Twitter.com/@evimsofian, Oktober 2021)

Hal tersebut diperburuk dengan pemberitahuan dari Project Multatuli yang disampaikan melalui akun Twitter (@projectm_org) pada 7 Oktober 2021 bahwa situs mereka tidak bisa dibuka akibat serangan DDoS (Denial-of-service), dua jam sejak publikasi artikel tersebut, Unggahan Project Multatuli terkait percobaan peretasan situs ini dapat kita lihat pada Gambar 2 di bawah. Sebagai akibat dari serangan peretasan tersebut, situs online projectmultuli.org tidak dapat diakses dan 
berita terkait pemerkosaan di Luwu Timur pun sulit dibaca oleh masyarakat yang ingin mengetahui kronologi kasus tersebut.

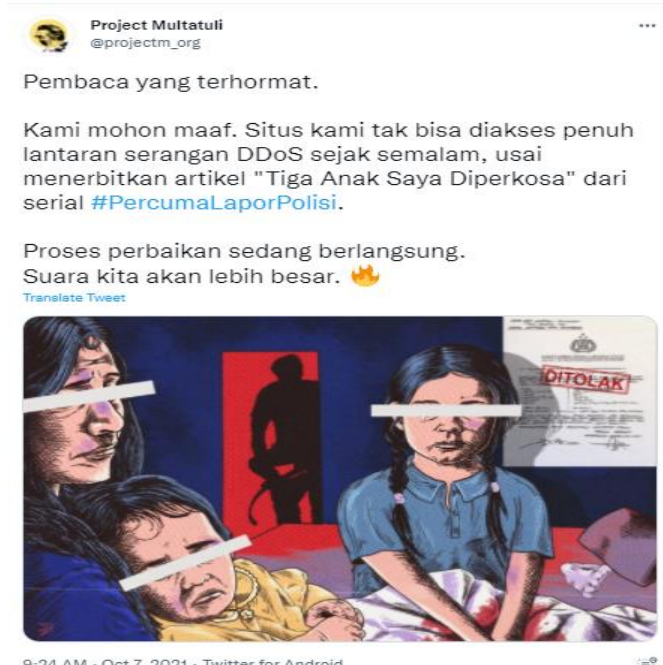

Gambar 2. Pemberitahuan melalui akun Twitter @ projectm_org mengenai peretasan situs (Sumber: Twitter.com, Oktober 2021)

Tidak hanya itu, pada Gambar 3 Project Multatuli juga menjelaskan bahwa unggahan konten terkait kasus tersebut sempat hilang dari Instagram mereka (@ projectm_org) karena dilaporkan oleh banyak pengguna Instagram lain sebagai konten yang melanggar ketentuan Instagram. Hal tersebut tentu dianggap tidak wajar karena secara substansi, unggahan terkait artikel tersebut tidak memenuhi unsur pelanggaran yang dimuat dalam Pedoman Pengguna Instagram.

3

Project Multatuli @projectm_org - Oct 7

konten di Instagram berjudul "Tiga Anak Saya Diperkosa, Saya Lapor ke Polisi. Polisi Menghentikan Penyelidikan." sementara telah hilang karena adanya report.

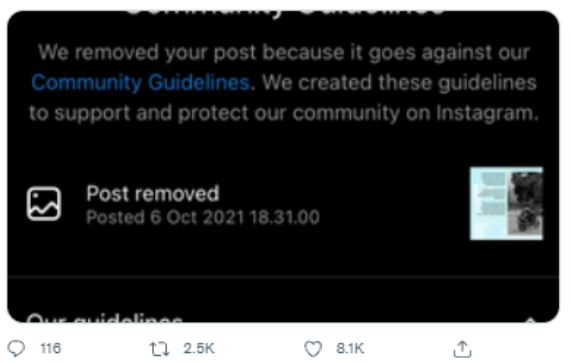

Gambar 3. Pemberitahuan melalui akun Twitter @ projectm_org mengenai hilangnya unggahan berita di Instagram

(Sumber: Twitter.com, Oktober 2021)
Rentetan kekecewaan dan kemarahan kepada badan kepolisian membuat para pengguna internet membangun solidaritas dengan berduyun-duyun menggunakan tagar \#PercumaLaporPolisi untuk menunjukkan protes mereka terkait inkompetensi badan penegak hukum ini dalam melaksanakan tugasnya untuk mengayomi masyarakat.

Widiatmoko (Aktivisme Tagar Dalam Kasus Pemerkosaan 3 Anak Di Luwu Timur, Mencari Keadilan Lewat Media Sosial Halaman All - Kompasiana.Com, n.d.) mencatat, dalam dua hari sejak pertama kali digunakan pada 6 Oktober 2021, tagar ini telah digunakan pada sebanyak 32.4 ribu cuitan warganet di Twitter. Sebagian besar cuitan dengan muatan tagar ini merupakan tanggapan atas berita kasus pemerkosaan anak yang dihentikan serta ungkapan kemarahan serta kekecewaan pengguna Twitter terkait hal-hal lain, termasuk pengalaman pribadi yang juga pernah merasakan kekecewaan terhadap kepolisian.

Tidak hanya berhasil menghimpun solidaritas pengguna internet, masifnya penggunaan tagar \#PercumaLaporPolisi serta kronologi kasus pemerkosaan di Luwu Timur ini juga berhasil menampilkan solidaritas media online di Indonesia. Hal ini tampak dari kesediaan berbagai media online di Indonesia untuk merepublikasi berita terkait kasus tersebut ketika situs Project Multatulis sedang menghadapi upaya peretasan. Beberapa media online lain yang turut melakukan republikasi artikel ini atas persetujuan Project Multatuli diantaranya Tirto.id, Vice Indonesia, Kompas.com, Suara.com, dan lain-lain (Twitter, 7 Oktober 2021).

Perhatian besar dalam skala nasional pada tagar \#PercumaLaporPolisi tidak hanya terbatas di media sosial, namun juga pada media online terkemuka di Indonesia. Beberapa media besar tercatat turut memublikasikan berita mengenai tagar \#PercumaLaporPolisi. Nampak pada Tabel 1, peneliti berhasil menemukan berbagai pemberitaan dari media terkemuka dengan 
muatan tagar \#PercumaLaporPolisi dalam judulnya.

Tabel 1. Publikasi Media Besar mengenai \#PercumaLaporPolisi

\begin{tabular}{|c|c|c|c|}
\hline Tanggal & Nama Media & Judul Berita & Isi Berita \\
\hline $\begin{array}{l}8 \text { Oktober } \\
2021\end{array}$ & Liputan6.com & $\begin{array}{l}\text { Tagar Percuma Lapor } \\
\text { Polisi Viral, Ini } \\
\text { Tanggapan Polri } \\
\text { Tagar }\end{array}$ & $\begin{array}{l}\text { Tanggapan Polri mengenai } \\
\text { viralnya tagar } \\
\text { \#PercumaLaporPolisi }\end{array}$ \\
\hline $\begin{array}{l}11 \text { Oktober } \\
2021\end{array}$ & republika.co.id & $\begin{array}{l}\text { \#PercumaLaporPolisi, } \\
\text { Polri Diminta Evaluasi } \\
\text { Internal }\end{array}$ & $\begin{array}{l}\text { Kronologis munculnya tagar } \\
\text { \#PercumaLaporPolisi dan } \\
\text { saran evaluasi untuk Polri }\end{array}$ \\
\hline $\begin{array}{l}13 \text { Oktober } \\
2021\end{array}$ & CNN Indonesia & $\begin{array}{l}\text { Keluh Warga Ramai } \\
\text { \#PercumaLaporPolisi: } \\
\text { Memang Percuma }\end{array}$ & $\begin{array}{l}\text { Tanggapan warga terkait } \\
\text { ramainya tagar } \\
\text { \#PercumaLaporPolisi }\end{array}$ \\
\hline $\begin{array}{l}14 \text { Oktober } \\
2021\end{array}$ & Jakarta Post & $\begin{array}{l}\text { "Why } \\
\text { \#PercumaLaporPolisi is } \\
\text { still a thing }\end{array}$ & $\begin{array}{l}\text { Kronologis munculnya tagar } \\
\text { \#PercumaLaporPolisi dan } \\
\text { alasan pembahasan tagar ini } \\
\text { tetap panjang }\end{array}$ \\
\hline $\begin{array}{l}23 \text { Oktober } \\
2021\end{array}$ & Tempo.co & $\begin{array}{l}\text { Ramai Tagar } \\
\text { \#PercumaLaporPolisi }\end{array}$ & $\begin{array}{l}\text { Infografis kronologi ramainya } \\
\text { tagar \#PercumaLaporPolisi }\end{array}$ \\
\hline
\end{tabular}

Sumber: Hasil pencarian penulis periode Oktober 2021

Penggunaan

\#PercumaLaporPolisi sebagai aktivisme tagar, merupakan fenomena yang sangat menarik di era digital ini. Aktivisme tagar menjadi hal yang baru terjadi dan hanya dapat terjadi dengan keberadaan internet penggunaan media sosial yang masif. Hal ini sejalan dengan konsep demokrasi siber atau cyber democracy yang secara umum merujuk pada kebebasan rakyat untuk berpartisipasi dalam aktivitas politik, berkumpul, berserikat, menyampaikan pendapat dan sebagainya yang dapat dilaksanakan tanpa sekat ruang atau secara online (dalam jaringan) (Zain et al., 2017). Salah satu contoh partisipasi dalam demokrasi siber dapat berupa penggunaan tagar dalam berbagai unggahan media sosial (aktivisme tagar) (Syahputra, 2017) seperti penggunaan tagar \#PercumaLaporPolisi yang telah kita singgung di atas.

Bila melihat dari perspektif yang lebih jauh, aktivisme tagar dapat kita sebut sebagai zeitgeist demokrasi siber di era digital ini. Zeitgeist mencakup berbagai set praktik, hubungan sosial, teknologi yang menjadi ciri khas dari masyarakat yang hidup pada periode waktu tertentu. Zeitgeist memiliki empat properti formal yang dirumuskan oleh Krause meliputi duration, scope, course serta media and carrier (Krause, 2019).

Kontekstualisasi zeitgeist sebagai 'semangat zaman' pada hal-hal yang sifatnya lebih baru telah diimplementasikan dalam penelitian sebelumnya yakni oleh Octoveria et al (Octoveria et al., 2019). Octoveria menggunakan konsep properti formal zeitgeist Krause, yang dibatasi pada 
salah satu properti formal saja yakni media. Melalui analisis yang dilakukan, Octoveria berhasil menunjukkan akun Instagram NKCTHI (Nanti Kita Cerita Tentang Hari Ini) sebagai zeitgeist dalam konteks sastra siber atau cyber literature. Akun Instagram NKCTHI menjadi sebuah representasi dari kondisi sastra siber saat ini dimana para pelakunya telah berpindah melakukan aktivitas terkait kesastraan, melalui akun media sosial yakni Instagram.

Selain itu, penelitian Prameswari juga menampilkan analisis zeitgeist pada visual iklan Coca-Cola dari waktu ke waktu (Prameswari, 2020). Analisis ini merupakan analisis semiotika yang fokus pada interpretasi objek visual. Selain dua penelitian ini, sayangnya peneliti tidak menemukan penelitian sejenis yang secara khusus berupaya mengidentifikasi zeitgeist pada hal-hal yang sifatnya lebih baru termasuk terkait demokrasi siber.

Berdasarkan hal tersebut, penelitian ini bertujuan untuk menemukan keberadaan keempat properti formal zeitgeist yang mengacu pada rumusan Krause pada aktivisme tagar sebagai bagian dari demokrasi siber di Indonesia. Penelitian seperti ini belum pernah dilakukan sebelumnya sehingga peneliti menilai analisis terkait hal ini penting dilakukan. Hasil dari penelitian ini dapat memberikan sumbangsih baru terhadap identifikasi zeitgeist pada masyarakat digital khususnya di bidang demokrasi siber.

\section{METODOLOGI}

Untuk mencapai tujuan penelitian, peneliti menggunakan metode penelitian netnografi. Dalam netnografi, terdapat tiga jenis data yang dapat digunakan yakni data arsip, data elisitasi dan data catatan lapangan (Bakry, 2017). Peneliti memfokuskan analisis pada penggunaan tagar \#PercumaLaporPolisi sehingga jenis data yang digunakan adalah data elisitasi dan data catatan lapangan.
Data elisitasi peneliti peroleh melalui software (perangkat lunak) Talkwalker untuk menganalisis penggunaan tagar \#PercumaLaporPolisi di Twitter. Sample data yang diambil oleh software Talkwalker merupakan analisis pada keseluruhan cuitan di Twitter yang mengandung tagar \#PercumaLaporPolisi pada periode 1-7 November 2021 dan 1-7 Desember 2021.

Data selanjutnya adalah data catatan lapangan yang peneliti temukan dalam analisis tagar \#PercumaLaporPolisi dalam kurun waktu kurang lebih dua bulan yakni sejak pertama kali tagar ini muncul pada 6 Oktober 2021 hingga 7 Desember 2021. Peneliti melakukan penelusuran dan eksplorasi penggunaan tagar ini di linimasa Twitter dalam kurun waktu tersebut. Tidak hanya itu, peneliti juga mencatat partisipasi platform lain seperti media online.

Berdasarkan data-data tersebut, peneliti melakukan analisis interpretif untuk dapat menjawab pertanyaan penelitian yakni terpenuhinya properti-properti formal zeitgeist dalam aktivisme tagar khususnya pada kasus tagar \#PercumaLaporPolisi.

\section{HASIL DAN PEMBAHASAN}

Merujuk pada paparan Kraust, terdapat empat properti formal yang menjadi elemen zeitgeist. Keempat properti formal tersebut adalah duration, scope, course serta media and carrier. Keempat properti formal ini dapat kita temukan dalam aktivisme tagar sebagai representasi semangat zaman dalam aktivitas demokrasi siber yang dilakukan oleh pengguna media sosial Twitter. Berikut penjelasan mengenai keempat properti formal dari zeitgeist demokrasi siber dalam aktivisme tagar khususnya ditelisik dari kasus tagar \#PercumaLaporPolisi.

\section{Duration (Durasi)}

Properti formal pertama yang diajukan oleh Kraust adalah duration atau durasi. Dalam konteks ini, kita perlu fokus pada linimasa atau histori waktu mengenai munculnya aktivisme tagar 
\#PercumaLaporPolisi sebagai wujud zeitgeist dalam demokrasi siber di Indonesia khususnya di Twitter.

Tagar \#PercumaLaporPolisi pertama kali dicuitkan oleh akun Twitter @ projectm_org yang membagikan hasil investigasi mereka melalui sebuah utas. Penggunaan kalimat \#PercumaLaporPolisi menunjukkan sikap skeptis media ini terhadap kepolisian yang tentunya tampak dari penggunaan kata "percuma". Melalui tagar ini, Project Multatuli menyatakan sikap mereka terhadap kinerja kepolisian dalam menangani laporan kasus hukum yang banyak dialami oleh masyarakat.

Cuitan pertama yang mengandung tagar \#PercumaLaporPolisi mendapatkan perhatian yang sangat besar dari pengguna Twitter. Cuitan ini berhasil memeroleh lebih dari 10.000 retweet, 1706 Quote Tweets dan lebih dari 18.000 likes. Berita yang memilukan, kronologi yang menyulut kemarahan serta cacat praktik hukum yang bersifat struktural menjadi isu yang kompleks, namun dapat tersimplifikasi dengan sangat representatif melalui tagar \#PercumaLaporPolisi yang digunakan oleh Project Multatuli.

Keberhasilan Project Multatuli merangkum kompleksitas kasus ini dengan memilih tagar \#PercumaLaporPolisi, menjadi salah satu sebab utama cuitan ini mendapatkan perhatian besar dan akhirnya sukses menjadi simbol dari gerakan aktivisme tagar dari pengguna Twitter dalam menunjukkan ketidakpercayaan mereka terhadap institusi kepolisian. Hal ini sejalan dengan pernyataan Lim (Lim, 2013) yang menyebut bahwa salah satu kunci dalam menciptakan aktivisme media sosial yang sukses adalah dengan melakukan simplifikasi pada keseluruhan narasi yang ingin disampaikan.

Kasus pemerkosaan anak di Luwu Timur hanyalah salah satu contoh kegagalan kepolisian dalam menjalankan prosedur penyelidikan kasus hukum. Penggunaan tagar \#PercumaLaporPolisi mampu menjadi simbol sederhana bagi perasaan kecewa atau pengalaman pengguna Twitter lain yang juga pernah menggalami sendiri maupun mendengar cerita orang terdekat saat melakukan laporan kepada kepolisian.

Setelah perhatian masyarakat terhadap kasus ini berlalu, tagar \#PercumaLaporPolisi masih terus digunakan oleh pengguna Twitter dalam menyampaikan kekecewaan mereka terhadap kinerja kepolisian. Salah satu contoh dapat dilihat pada Gambar 4 yang menunjukkan seorang pengguna Twitter mencuitkan persepsinya terhadap aparat kepolisian terkait kasus pembunuhan yang dilakukan RD, warga Bengkulu kepada pemerkosa istirnya. Melalui cuitan ini, pengguna Twitter menyatakan pendapatnya bahwa penyebab RD melakukan pembunuhan terhadap pemerkosa istrinya, disebabkan oleh rasa tidak percaya bahwa aparat akan membantunya mengusut kasus yang dialami istrinya. Cuitan ini disertai dengan tagar \#PercumaLaporPolisi yang kian menguatkan sisi emosional dan menunjukkan rasa tidak percaya kepada kepolisian.

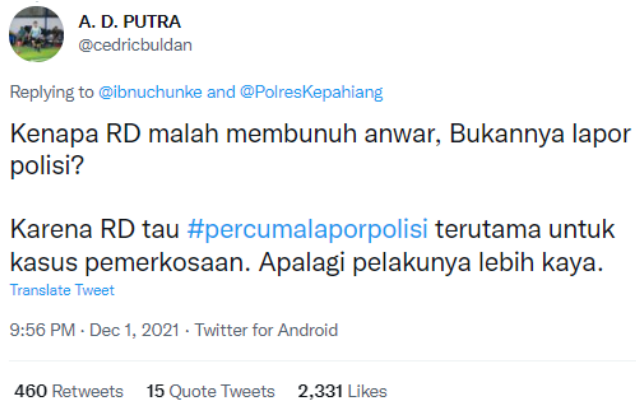

Gambar 4. Contoh penggunaan tagar \#PercumaLaporPolisi pada konteks kasus pembunuhan.

(Sumber: Twitter.com, Desember 2021)

Tidak berhenti sampai di situ, sejak viralnya tagar ini, pengguna Twitter ternyata terus menggunakan \#PercumaLaporPolisi dalam cuitan-cuitan terkait kasus yang menyangkut kekecewaan pada kepolisian. Kasus terbaru yang juga menjadi perhatian pengguna Twitter adalah kasus kematian 
seorang mahasiswi bernama Novia Widya Sari yang bunuh diri karena diperkosa, dipaksa melakukan aborsi oleh kekasihnya yang adalah seorang pegawai kepolisan bernama Randy Bagus Hari Sasongko. Tidak hanya karena pelaku merupakan aparat kepolisian, fakta bahwa Novia Widya Sari sebelumnya telah berusaha melaporkan kejadian ini ke pihak kepolisian namun tidak mendapatkan tindak lanjut yang seharusnya, membuat publik kembali mengangkat tagar \#PercumaLaporPolisi.

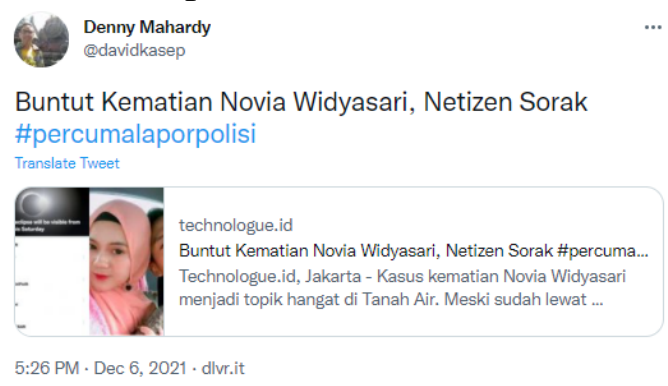

Gambar 5. Penggunaan tagar \#PercumaLaporPolisi dalam cuitan terkait berita kematian Novia Widyasari.

(Sumber: Twitter.com, Desember 2021)

Pada contoh Gambar 5, kita bisa melihat bahwa pengunaan tagar \#PercumaLaporPolisi secara berkala ramai digunakan kembali oleh pengguna Twitter dalam menanggapi berbagai kasus yang terjadi di negeri ini. Hal ini dapat kita konfirmasi kembali melalui Gambar 6 yang menampilkan analisis software Talkwalker. Grafik menunjukkan peningkatan aktivitas penggunaan tagar \#PercumaLaporPolisi pada 1-7 Desember 2021, bersamaan dengan ramainya kasus kematian Novia Widya Sari.

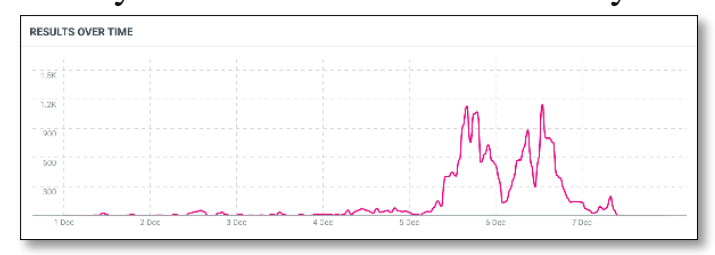

Gambar 6. Grafik peningkatan penggunaan tagar \#PercumaLaporPolisi pada 1-7 Desember 2021

(Sumber: Talkwalker, Desember 2021)
Berdasarkan hal tersebut, dapat kita tarik kesimpulan bahwa durasi penggunaan tagar \#PercumaLaporPolisi dimulai pada 6 Oktober 2021 dan terus digunakan oleh pengguna Twitter. Durasi penggunaan tagar ini tidak berhenti dengan berlalunya kasus pemerkosaan di Luwu Timur. Kekuatan dan ketepatan tagar ini dalam mewakili emosi dan kekecewaan masyarakat terhadap kepolisian menjadikan durasi penggunaan tagar ini dapat diasumsikan terus berlangsung hingga waktu yang belum dapat diidentifikasi.

Dengan demikian dapat kita simpulkan bahwa tagar \#PercumaLaporPolisi memenuhi aspek duration yang menjadi salah satu properti formal sebagai zeitgeist demokrasi siber di Indonesia.

\section{Scope}

Properti formal scope atau jangkauan, merujuk pada paparan Kraust, adalah ruang sosial atau geografis berlangsungnya sebuah peristiwa atau zaman. Kraust juga memaparkan bahwa scope menunjukkan ranah pengaruh sebuah aktivitas atau fenomena secara lebih kuat pada satu kelompok sosial dari kelompok sosial yang lain.

Terkait hal tersebut, kita dapat melihat beberapa temuan yang berhasil peneliti kumpulkan dalam analisis persebaran tagar \#PercumaLaporPolisi di Twitter. Analisis dilakukan menggunakan software online Talkwalker dalam rentang analisis pada 1-7 November 2021.

Melalui software Talkwalker, kita dapat menganalisis demografi pengguna Twitter yang menerbitkan cuitan terkait berbagai hal dengan menyertakan tagar \#PercumaLaporPolisi. 


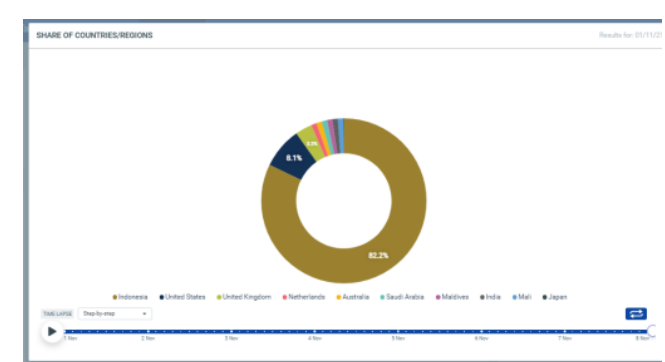

Gambar 7. Persebaran geografis cuitan dengan tagar \#PercumaLaporPolisi

(Sumber: Talkwalker, November 2021)

Pada Gambar 7, kita dapat melihat sebaran geografis penggunaan tagar \#PercumaLaporPolisi. Dalam gambar berupa diagram tersebut, nampak bahwa $82.2 \%$ atau sebagian besar cuitan menggunakan tagar \#PercumaLaporPolisi berasal dari pengguna Twitter yang berlokasi di Indonesia. Sisanya adalah pengguna Twitter yang berlokasi di Amerika Serikat $(8.1 \%)$, Inggris 3.3\%, dan Belanda, Arab Saudi, India, Australia serta Mali dengan persentase masing-masing $1.1 \%$.

Tidak jauh berbeda dengan klasifikasi geografis, pada Gambar 8 kita dapat melihat diagram komposisi bahasa yang digunakan dalam cuitan yang menyertakan tagar \#PercumaLaporPolisi. Bahasa cuitan didominasi oleh bahasa Indonesia (94.3\%), selanjutnya bahasa Inggris (3.5\%), bahasa Melayu (1.2\%) dan bahasa India (1.1\%)

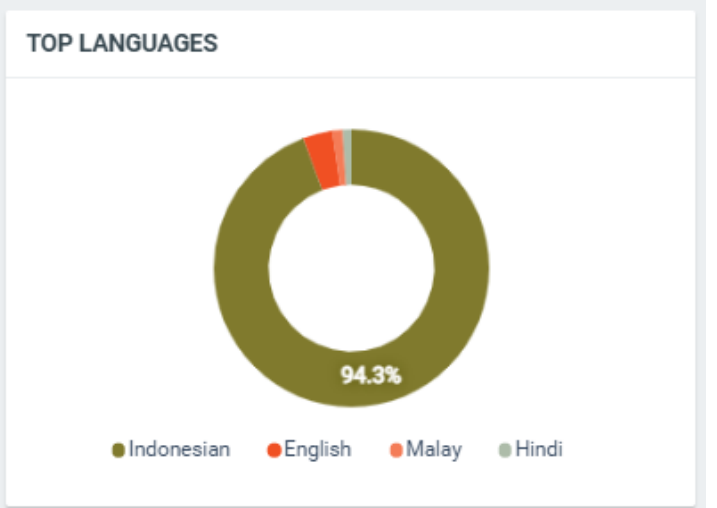

Gambar 8. Komposisi penggunaan bahasa dalam cuitan \#PercumaLaporPolisi (Sumber: Talkwalker, November 2021)
Data terakhir yang menunjukkan scope atau jangkauan aktivisme tagar, dari sisi demografi dapat dianalisis pula dari elemen usia. Melalui Gambar 9, kita dapat melihat hasil analisis aplikasi Talkwalker, menunjukkan bahwa perbincangan di Twitter dengan tagar \#PercumaLaporPolisi terjadi pada rentang usia 18-54 tahun. Hal ini kemungkinan disebabkan pula oleh demografi umum dari Twitter yang didominasi oleh pengguna berusai $18-50$ tahun.

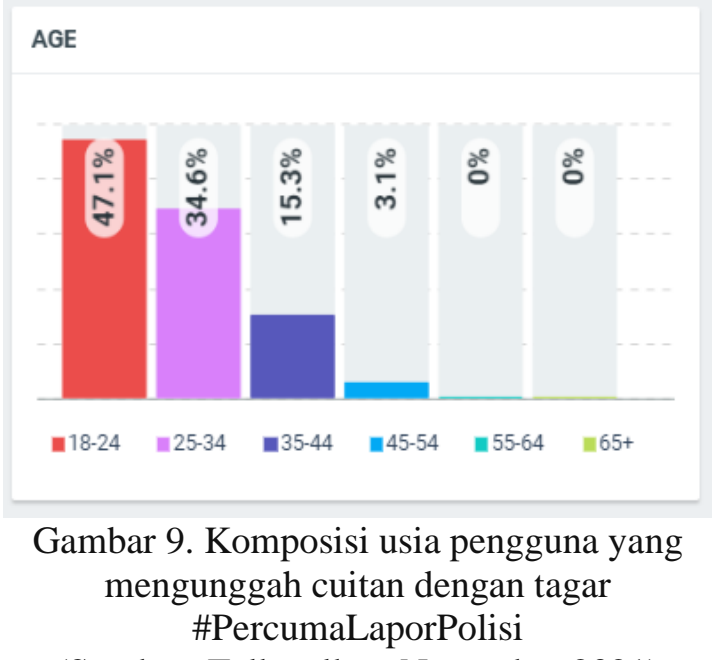

(Sumber: Talkwalker, November 2021)

Berdasarkan data yang ditunjukkan Gambar 7, Gambar 8, dan Gambar 9 dapat kita tarik kesimpulan bahwa aktivisme tagar di Twitter memiliki jangkauan atau scope dalam aspek geografi maupun demografi. Melalui analisis tagar \#PercumaLaporPolisi, dapat terlihat bahwa jangkauan gerakan ini bersifat lokal karena sebagian besar menjangkau pengguna Twitter yang berlokasi di Indonesia. Selain itu, aktivisme tagar ini juga dapat terlihat dominan melibatkan pengguna berusia 18 hingga 54 tahun. Berbagai temuan di atas dapat kita jadikan landasan interpretasi bahwa aktivisme tagar telah memenuhi aspek properti formal kedua sebagai sebuah zeitgeist, yakni properti formal scope atau jangkauan. Tidak hanya memenuhi aspek secara geografis dan demografis, berdasarkan data tersebut, kita juga dapat 
melihat bahwa gerakan aktivisme tagar ini, cenderung lebih berdampak pada pengguna media sosial Twitter berusia 18-54 tahun yang berada di Indonesia serta menggunakan bahasa Indonesia dibandingkan golongan masyarakat di kelompok lain.

\section{Course}

Properti formal ketiga yang direkomendasikan Krause adalah course yang secara bebas dapat kita terjemahkan sebagai 'arah' atau 'arus'. Properti formal ini merupakan sintesis dari dua properti sebelumya yakni duration dan scope. Properti formal course dapat dijelaskan melalui perkembangan scope zeitgeist dari satu ke waktu. Course dari zeitgeist adalah perjalanan dari sebuah fenomena atau ciri khusus dalam muncul, berkembang dan kemudian surut hingga hilang dalam suatu masyarakat.

Oleh karena zeitgeist adalah fenomena yang terjadi dengan alamiah, maka perkembangannya bisa berbeda-beda antara satu hal dengan lainnya. Sebuah zeitgeist dapat berkembang secara perlahan dan lambat, atau sebaliknya secara cepat dan tiba-tiba. Zeitgeist dapat muncul pada satu golongan tertentu saja dan kemudian merambah pada golongan lain, atau sebaliknya secara eksklusif dan terbatas hanya berlaku pada kelompok tertentu.

Dalam kaitannya dengan aktivisme tagar, kita dapat melihat keberlangsung hal ini dalam scope dan duration. Berdasarkan paparan pada properti formal duration, dapat terlihat bahwa penggunaan tagar \#PercumaLaporPolisi muncul pertama kali pada 6 Oktober 2021 dari cuitan akun @projectm_org dalam publikasi kasus pemerkosaan anak di Luwu Timur. Ketepatan pemilihan kalimat dalam tagar ini selanjutnya menjadi kekuatan yang membuat pengguna Twitter masih terus menggunakannya dalam menanggapi beragam kasus lain yang muncul ke permukaan.
Penggunaan tagar ini, pada praktiknya bisa disandingkan dengan tagar lain yang secara spesifik merujuk kasus yang sedang dibicarakan. Pada Gambar 10 terlihat berbagai tagar lain yang sering digunakan dalam cuitan bersamaan dengan tagar \#PercumaLaporPolisi yang ditampilkan oleh analisis Talkwalker pada 1-7 Desember 2021, dua bulan setelah pertama kali tagar ini viral.

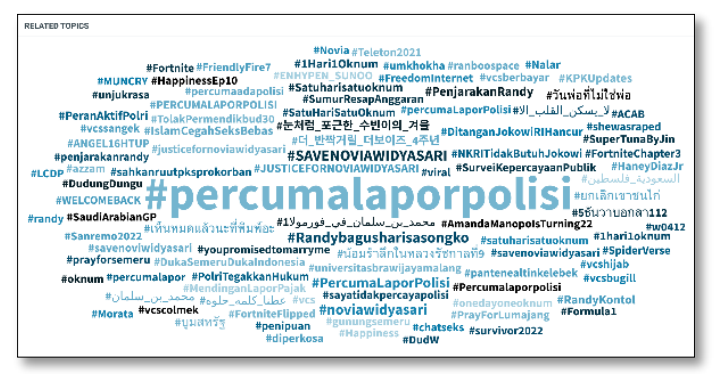

Gambar 10. Topik terkait yang muncul bersama tagar \#PercumaLaporPolisi

(Sumber: Talkwalker, Desember 2021)

Dalam Gambar 10 tampak berbagai tagar lain yang menjadi topik terkait dan digunakan dalam sebuah cuitan bersamaan dengan tagar \#PercumaLaporPolisi. Beberapa tagar lain yang tampak dalam analisis tersebut yakni \#SaveNoviaWidyaSari, \#penipuan, \#1Hari1Oknum, \#sayatidakpercayapolisi, \#SahkanRUUPKSProKorban, \#diperkosa dan sebagainya.

Berdasarkan data pada Gambar 10 kita dapat melihat keberlangsung 'arah' dari penggunaan tagar \#PercumaLaporPolisi dalam konteks aktivisme tagar dalam demokrasi siber di media sosial Twitter. Penggunaan tagar ini, dapat terus dikontekstualisasikan kembali disandingkan dengan berbagai jenis kasus dan peristiwa yang muncul, dialami dan diketahui oleh pengguna Twitter. Pengguna Twitter dengan mudah dan tepat bisa kembali menggunakan tagar ini sebagai wujud ekspresi dan protes mereka terhadap kerja kepolisian.

Dengan demikian, kita dapat menyepakati bahwa aktivisme tagar memenuhi properti formal ketiga dalam 
zeitgeist yakni course karena dapat dilihat perkembangannya baik secara durasi maupun jangkauan dari waktu ke waktu.

\section{Media and Carrier}

Properti formal terakhir yang didiskusikan adalah media and carrier atau 'media dan pembawa'. Krause memaparkan bahwa media and carrier terkait penjelasan mengenai area sebuah gagasan dimuat bersama, dengan mudah didistribusikan dan membangun sebuah perintah/keteraturan dan dipaparkan dalam dan melalui koherensi internal masing-masing.

Berdasarkan penjelasan tersebut, kita dapat mengidentifikasi media and carrier aktivisme tagar adalah media sosial, khususnya Twitter yang secara durasi, jangkauan maupun arah, konsisten digunakan sebagai medium dalam pembentukan dan penyebaran gagasan.

Hal serupa dapat kita temukan dalam contoh kasus tagar \#PercumaLaporPolisi. Sesuai dengan paparan di atas, tagar ini pertama kali muncul di Twitter. Media yang sama terus mendominasi sebagai media and carrier yang menjadi sarana gagasan mengenai \#PercumaLaporPolisi terus direproduksi dan disebarluaskan.

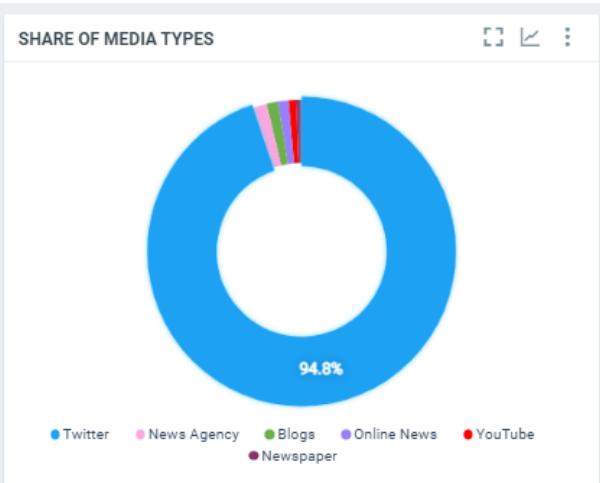

Gambar 11. Komposisi media penyebaran tagar \#PercumaLaporPolisi

(Sumber: Talkwalker, November 2021)

Pada Gambar 11, kita secara jelas dapat melihat komposisi media yang digunakan dalam menyebarkan narasi terkait \#PercumaLaporPolisi. Twitter menjadi media dominan dengan persentase sebesar $94.8 \%$, diikuti dengan agensi berita (1.5\%), blog $(1.2 \%)$, berita online (1.1\%), Youtube $(0.8 \%)$, dan koran $(0.6 \%)$.

Dengan demikian, dapat disimpulkan bahwa media and carrier dalam aktivisme tagar sebagai zeitgeist dari demokrasi siber di Indonesia, adalah Twitter.

\section{SIMPULAN}

Berdasarkan berbagai temuan di atas, terkonfirmasi bahwa aktivisme tagar memuat empat properti formal zeitgeist yakni duration, scope, course, serta media and carrier.

Duration tampak pada dimulainya penggunaan tagar \#PercumaLaporPolisi oleh akun Twitter @projectm_org pada 6 Oktober 2021 sebagai bagian dari utas mereka dalam memberitakan hasil investigasi kasus pemerkosaan anak di Luwu Timur. Meskipun perhatian masyarakat terhadap kasus tersebut telah mereda, analisis software Talkwalker menunjukkan penggunaan tagar ini masih terus berlangsung dan menunjukkan grafik yang dinamis bergantung dari munculnya kasuskasus lain yang terkait dengan kepolisian.

Scope tampak dari data persebaran geografi dan demografi pengguna Twitter yang menunjukkan aktivitas penyampaian opini melalui cuitan dengan menyertakan tagar \#PercumaLaporPolisi pada umumnya terjadi pada pengguna aplikasi Twitter yang tinggal di Indonesia, menggunakan bahasa Indonesia, serta dalam rentang usia 18 hingga 54 tahun.

Selanjutnya, properti formal course ditunjukkan dengan konsistensi penggunaan tagar \#PercumaLaporPolisi yang dikatikan dengan topik-topik baru yang masih tepat konteks dan relevan. Pengguna Twitter menunjukkan potensi besar dalam menggunakan kembali tagar ini dalam komunikasi mereka di Twitter dalam menanggapi berbagai kasus lain yang terjadi di masa mendatang. 
Terakhir, properti formal media and carrier ditunjukkan dengan dominasi Twitter dalam proses pembentukan, penyebaran dan pemahaman konteks aktivisme tagar \#PercumaLaporPolisi. Meski penggunaan tagar \#PercumaLaporPolisi juga ditemukan pada platform lain seperti Instagram maupun media online, namun dapat kita sepakati bahwa Twitter masih menjadi media and carrier utama yang dimanfaatkan dalam menyebarluaskan tagar ini.

Berdasarkan hasil analisis di atas, dapat kita simpulkan bahwa aktivisme tagar

\section{DAFTAR PUSTAKA}

Aktivisme Tagar dalam Kasus Pemerkosaan 3 Anak di Luwu Timur, Mencari Keadilan Lewat Media Sosial Halaman all - Kompasiana.com. (n.d.). Retrieved November 11, 2021, from https://www.kompasiana.com/fery509 73/615fafca06310e561e2f5bc2/mencar i-keadilan-lewat-mediasosial?page $=$ all

Bakry, U. S. (2017). Pemanfaatan Metode Etnografi dan Netnografi Dalam Penelitian Hubungan Internasional. Jurnal Global \& Strategis, 11(1), 15. https://doi.org/10.20473/jgs.11.1.2017. $15-26$

Bonilla, Y., \& Rosa, J. (2015). \#Ferguson: Digital protest, hashtag ethnography, and the racial politics of social media in the United States. American Ethnologist, 42(1), 4-17. https://doi.org/10.1111/amet.12112

Carley, K. M., Malik, M., Kowalchuck, M., Pfeffer, J., \& Landwehr, P. (2018). Twitter Usage in Indonesia. SSRN Electronic Journal, December. https://doi.org/10.2139/ssrn.2720332

Clark, R. (2016). "Hope in a hashtag": the discursive activism of \#WhyIStayed. Feminist Media Studies, 16(5), 788804.

https://doi.org/10.1080/14680777.2016 telah memenuhi keseluruhan properti formal sebagai zeitgeist demokrasi siber di Indonesia.

Selanjutnya, perlu dilakukan penelitian lebih lanjut secara lebih mendalam dan obyek analisis yang lebih beragam, misalnya perbandingan analisis pada contoh tagar lain yang juga berhasil disuarakan di Twitter. Alternatif eksplorasi penelitian lain dapat berupa pemilihan media sosial yang secara tren dan popularitas memiliki performa lebih baik dibandingkan Twitter, seperti Instagram, TikTok maupun Youtube.

\section{.1138235}

Digital in Indonesia: All the Statistics You Need in 2021 - DataReportal-Global Digital Insights. (n.d.). Retrieved November 11, 2021, from https://datareportal.com/reports/digital -2021-indonesia

Global Twitter user age distribution 2021 | Statista. (n.d.). Retrieved November 11, 2021, from https://www.statista.com/statistics/283 119/age-distribution-of-global-twitterusers/

Kementerian Komunikasi dan Informatika. (n.d.). Retrieved November 11, 2021, from

https://kominfo.go.id/content/detail/23 66/indonesia-peringkat-limapenggunatwitter/0/sorotan_media

Krause, M. (2019). What is Zeitgeist? Examining period-specific cultural patterns. Poetics, 76(February), 0-1. https://doi.org/10.1016/j.poetic.2019.0 2.003

Lim, M. (2013). Many Clicks but Little Sticks: Social Media Activism in Indonesia. Journal of Contemporary Asia, 43(4), 636-657. https://doi.org/10.1080/00472336.2013 .769386

Mencuat Lagi Cicak Vs Buaya di Tubuh KPK, Begini Sejarahnya. (n.d.). 
Retrieved November 11, 2021, from https://news.detik.com/berita/d5561874/mencuat-lagi-cicak-vs-buayadi-tubuh-kpk-begini-sejarahnya/

Octoveria, E. N., Femigasari, N., \& Athali, N. (2019). Capturing Zeitgeist on Cyber Literature: a Case of @ Nkcthi on Instagram. Poetika, 7(2), 158. https://doi.org/10.22146/poetika.v7i2.5 1207

Prameswari, N. S. (2020). Tinjauan Histori Pada Gaya Visual Iklan Cetak CocaCola. 02, 24-37.

Saifulloh, M., \& Ernanda, A. (2018). Manajemen Privasi Komunikasi Pada Remaja Pengguna Akun Alter Ego Di Twitter. WACANA, Jurnal Ilmiah Ilmu Komunikasi, 17(2), 235. https://doi.org/10.32509/wacana.v17i2 .652

Syahputra, I. (2017). Demokrasi Virtual Dan Perang Siber Di Media Sosial: Perspektif Netizen Indonesia. Jurnal ASPIKOM, $3(3), \quad 457$. https://doi.org/10.24329/aspikom.v3i3. 141

Tiga Anak Saya Diperkosa, Saya Lapor ke Polisi. Polisi Menghentikan Penyelidikan. - Project Multatuli. (n.d.). Retrieved November 11, 2021, from https://projectmultatuli.org/kasuspencabulan-anak-di-luwu-timur-polisimembela-pemerkosa-danmenghentikan-penyelidikan/

Yang, G. (2016). Narrative agency in hashtag activism: The case of \#blacklivesmatter. Media and Communication, 4(4), 13-17. https://doi.org/10.17645/mac.v4i4.692

Zain, Z. M., Yusoff, M. A., \& Othman, Z. (2017). Internet dan kebangkitan demokrasi siber di Malaysia: Analisis Pilihan Raya Umum 1999 dan 2008 (The Internet and the rise of Malaysian cyber democracy: An analysis of the 1999 and 2008 General Elections). Geografia - Malaysian Journal of Society and Space, 11(6), 56-66. 